\title{
ЦИТ: ua117-115
}

DOI: $10.21893 / 2415-7538.2016-05-1-115$

СУЧАСНІ ПРОБЛЕМИ СТВОРЕННЯ ВИСОКОПРОДУКТИВНИХ РОБОЧИХ МІСЦЬ В УКРАЇНІ

\author{
(тези)
}

Інститут підготовки кадрів державної служби зайнятості Украӥни Киев, Нововокзальна 17, 03038

Mazurov S.A.

\section{MODERN PROBLEMS CREATION OF HIGHLY JOBS IN UKRAINE}

\section{(abstracts)}

Institute of personnel training state employment service of Ukraine

Kiev, Novovokzalnaya 17, 03038

Анотачія. В даній науковій роботі розглядаються сучасні проблеми державної регуляторної політики України, пов'язані з відсутністю методик моніторингу створення нових та високопродуктивних робочих місцьь.

Ключові слова: високопродуктивні робочі місчя, моніторинг, показники, економічна програма.

Abstract. In this scientific work deals with modern problems of state regulatory policy of Ukraine related to the lack of monitoring techniques development of new high-performance workplaces.

Keywords: high performance workplaces, monitoring, indicators, economic program.

Створення нових робочих місць - безперечний атрибут розвинутої державної економічної моделі, що, викликає активізацію майже всіх державних регуляторно-економічних процесів. Проте, ми згодні 3 правильністю твердження, що створення нового робочого місця не $\epsilon$ інструментом досягнення стабільного економічного зростання країни. Для цього новостворене робоче місце повинно характеризуватись високою продуктивністю праці. Дана концепція може бути реалізована тільки за допомогою залучення прямої державної підтримки та інструментів економічної політики. Однак, на сьогодні в даному напрямку спостерігається регрес та пасивність 3 боку державної влади, тому актуальність проблеми створення не просто робочих, а саме високопродуктивних робочих місць змушує винести іiі якщо не на перше місце проблем сучасної економіки України, то із впевненістю ставить в трійку основних.

На державному рівні вже були створені певні економічні програми по створенню нових робочих місць, що відзначались перспективністю, виходячи 3 їх основних завдань та функцій. Однак, створення нових, а тим більше високопродуктивних робочих місць, неможливе без їх моніторингу та систематизації даних.

В рамках Національного плану дій на 2013 рік щодо впровадження Програми економічних реформ на 2010-2014 роки "Заможне суспільство, конкурентоспроможна економіка, ефективна держава" була затверджена 
«Методика моніторингу створення нових робочих місць», яка покликана була надати сучасний інструмент збору та систематизації статистичних даних для подальшого їх впровадження в систему реалізації державної економічної політики щодо створення нових робочих місць.

Дана методика визначає порядок розрахунку, збору та узагальнення показників, що характеризують чисельність осіб, прийнятих на роботу на створені нові робочі місця, та чисельність осіб, звільнених внаслідок змін в організації виробництва і праці, у розрізі адміністративно-територіальних одиниць і за видами економічної діяльності. Крім цього, згідно з методикою визначаються суб'єкти, які можуть створювати робочі місця та працевлаштовувати на них осіб, та надаються методичні підходи щодо обліку створення нових робочих місць у розрізі адміністративно-територіальних одиниць та за видами економічної діяльності.

Чисельність прийнятих на роботу на створені нові робочі місця обчислюється наростаючим підсумком 3 початку року шляхом додавання показників щодо чисельності прийнятих на роботу на створені нові робочі місця у юридичних осіб та у фізичних осіб. А чисельність осіб, звільнених у зв'язку зі змінами в організації виробництва і праці, обчислюється шляхом додавання показників щодо чисельності працівників, звільнених у юридичних осіб внаслідок ліквідації, реорганізації, банкрутства або перепрофілювання підприємства, установи, організації, скорочення чисельності або штату працівників та у фізичних осіб наростаючим підсумком з початку року[1].

Аналізуючи дану методику, слід вказати на різновекторність цілей та завдань, які повинна ставити перед собою ця методика. Як зазначається в іiі загальних положеннях, спостереженню підлягають лише прийняті та звільнені працівники, що є взагалі некоректним за умов реалізації функцій моніторингу створення нових робочих місць. Тобто, на законодавчому рівні запропоновано підхід, що моніторить не створення нових робочих місць, а їх укомплектування працівниками (персоналом), тобто $є$ статистичним інструментарієм щодо визначення кількості прийнятих $\mathrm{i}$ звільнених 3 роботи, що $€$ позитивним аспектом вказаного документу. Проте, в цілому цей підхід не може бути застосований до моніторингу створення нових робочих місць, зокрема високопродуктивних. 3 цього випливає висновок, що в Україні досі не створено методичних підходів до моніторингу створення високопродуктивних та ефективних робочих місць.

Водночас слід відмітити, що у зарубіжній практиці були розроблені відповідні методики. Так, російська методика розрахунку показника «Приріст високопродуктивних робочих місць у відсотках до попереднього року», методика розрахунку показників "Частка продукції високотехнологічних i наукоємних галузей у валовому внутрішньому продукті", а також "Частка продукції високотехнологічних і наукоємних галузей у валовому регіональному продукті суб'єкта Російської Федерації" мають дуже чіткі сформовані цілі та завдання, i на відміну від вітчизняної методики, дійсно спрямовані на розрахунки показників динаміки високопродуктивних робочих місць. Згідно 3 ïx методикою, до високопродуктивних робочих місць відносяться всі заміщені 
робочі місця підприємства (організації), на якому середньомісячна заробітна плата працівників (для індивідуальних підприємців - середня виручка) дорівнює або перевищує встановлену величину критерію (граничне значення). В якості критерію для відбору організацій (підприємств), які мають високопродуктивні робочі місця, встановлюється порогове значення середньомісячної заробітної плати працівників на одне заміщення робоче місце, диференційоване за типами підприємств і суб'єктів економіки [2].

В Україні основні перепони на шляху створення високопродуктивних робочих місць полягають в тому, що на загальнодержавному рівні не сформульовано стратегічної мети реформування економіки. Як показує дослідження, економіка України справляє попит на низькооплачувані та непродуктивні робочі місця. Робочі місця створюються у технологічно відсталих галузях. 3 огляду на наближення демографічної кризи, яка очікується після 2020 р., та старіння населення України, нові робочі місця повинні вирішити завдання матеріального добробуту не лише працюючих, а й зростаючої кількості пенсіонерів, співвідношення яких до того часу буде 1,5 до 1 (зараз - 3 до 1). Тобто, нові робочі місця повинні забезпечувати вищу, ніж сьогодні продуктивність праці, щоб виконувати державну функцію різних рівнів[3].

Таблиця

\section{Динаміка продуктивності праці в цілому по економіці та промисловості}

\section{України}

\begin{tabular}{|l|c|c|c|}
\hline \multicolumn{1}{|c|}{ Показники } & $\mathbf{2 0 1 3}$ & $\mathbf{2 0 1 4}$ & $\mathbf{2 0 1 5}$ \\
\hline $\begin{array}{l}\text { Продуктивність праці на одного зайнятого в цілому по } \\
\text { економіці (в цінах попереднього року, тис грн.) }\end{array}$ & 75.76 & 87.08 & 124.99 \\
\hline $\begin{array}{l}\text { Індекс приросту (зменшення) продуктивності праці на одного } \\
\text { зайнятого цілому по економіці (в цінах попереднього року, \%) }\end{array}$ & 1.07 & 1.04 & 1.15 \\
\hline $\begin{array}{l}\text { Продуктивність праці на одного зайнятого в цілому по } \\
\text { промисловості (в цінах попереднього року, тис грн.) } \\
\text { (переробна та добувна промисловість сумарно) }\end{array}$ & 74.39 & 75.75 & 90.39 \\
\hline $\begin{array}{l}\text { Індекс приросту (зменшення) продуктивності праці на одного } \\
\text { зайнятого цілому по промисловості (в цінах попереднього } \\
\text { року, \%) }\end{array}$ & 1.02 & 1.02 & 1.19 \\
\hline
\end{tabular}

(без урахування тимчасово окупованої території Автономної Республіки Крим, м. Севастополя та частини зони проведення антитерористичної операціï)

Як свідчать розрахунки, зростання продуктивності праці не відображає об'єктивний процес створення високопродуктивних робочих місць.

Таким чином, методичні, методологічні та прикладні питання створення високопродуктивних робочих місць в економіці, і особливо в промисловості, вивчені не повністю. I прийняття ефективних управлінських рішень на макрорівні щодо створення нових високопродуктивних робочих місць в промисловості потребує розробки методичного забезпечення не тільки розрахунків їх кількості, але й аналізу як процесу.

Список використаних джерел

1. Наказ міністерства соціальної політики № 611 від 23.09.2013p. «Про 
затвердження Методики моніторингу створення нових робочих місць» //[Електронний ресурс] // Верховна рада України. - Режим доступу: http://zakon0.rada.gov.ua/laws/show/z1749-13

2. Методика расчета показателя «Прирост высокопроизводительных рабочих мест в процентах к предыдущему году»//[Електронний ресурс] //Режим доступу:http://lawru.info/dok/2013/11/14/n7015.htm

3. Створення нових робочих місць в Україні: Результати та перспективи // Національний інститут стратегічних досліджень. [Електронний ресурс] Режим доступу: http://old.niss.gov.ua/Monitor/october09/15.htm/

4. Кожем'якіна С.M. Продуктивність праці на макрорівні: визначення, аналіз та прогнозування : монографія / Кожем'якіна С.М. - К. : ТОВ «НВП «нттерсервіс», 2012. - 374 с.

Науковий керівник: д.е.н. Кожем'якіна С.М. Стаття відправлена: 08.04.2017p.

(C) Мазуров С.A.

ЦИТ: иа117-097

DOI: 10.21893/2415-7538.2016-05-1-097

Силина Т.А., Тхакушинова С.А. СПЕЦИАЛЬНЫЕ НАЛОГОВЫЕ РЕЖИМЫ ДЛЯ МАЛЫХ ФОРМ РЕСТОРАННО-ГОСТИНИЧНОГО БИЗНЕСА

(НА ПРИМЕРЕ МО Г. МАЙКОП)

Адыгейский государственный университет

Майкоп, ул. Первомайская 208, 385000

Silina T.A., Tkhakushinova S. A.

SPECIAL TAX REGIMES FOR SMALL FORMS

OF RESTAURANT AND HOTEL BUSINESS

(ON THE EXAMPLE OF THE MUNICIPAL ENTITY "CITY OF MAIKOP")

Adyghe state University,

Russia, Republic of Adygea, Maikop, Pervomayskaya str., 208, 385000

Аннотация. В статье на примере муниципального образования «Город Майкоп» представлена методика оченки специальных режимов налогообложения для ресторанно-гостиничных комплексов с точки зрения выбора наиболее оптимального. Рассмотрены единый налог на вмененный доход и два варианта упрощенной системь налогообложения (УСН). $B$ качестве основных критериев оченки выделены: размер налоговых платежей и затраты на организацию налогового учета.

Ключевые слова: специчальный налоговый режим, ресторанногостиничный комплекс, ЕНВД, упрощуенная система налогообложения, мальй бизнес.

Abstract. The article on the example of the municipal entity "City of Maikop" presents a methodology for assessing special taxation regimes for restaurant and hotel complexes in terms of choosing the most optimal. A single tax on imputed income and two versions of the simplified taxation system are considered. As the 